\title{
RECENZJE
}

\section{MAREK SOBCZYK Siła wyższa w rzymskim prawie prywatnym, Wydawnictwo TNOiK, Toruń 2005, ss. 331}

W przeciągu ostatniego dziesięciolecia polska literatura wzbogaciła się o szereg wartościowych prac stanowiących monograficzne ujęcie poszczególnych instytucji i zasad prawa rzymskiego tak prywatnego, jak i publicznego, dotąd szczególowo nie badanych'. Ukazały się opracowania dotyczące takich zagadnień jak np.: dobra wiara (bona fides) ${ }^{2}$, rzymski proces cywilny ${ }^{3}$ i karny ${ }^{4}$, tempus lugen$d i^{5}$, infamia ${ }^{6}$, obligationes quasi ex delicto ${ }^{7}$ czy nadużycie prawa ${ }^{8}$. Obecnie do grona przybliżonych polskiemu czytelnikowi instytucji i konstrukcji właściwych prawu rzymskiemu dołącza zagadnienie siły wyższej (vis maior), opracowane przez toruńskiego romanistę Marka Sobczyka. Jest to pierwsza praca w języku polskim dotycząca tej tematyki w kontekście prawa rzymskiego, wielokrotnie nato-

\footnotetext{
' Por. M. ZABŁoCKA, Romanistyka polska po II wojnie światowej, Warszawa 2002

'W. DAJCZAK Zwrot 'bona fides' $w$ rozstrzygnięciach dotyczących kontraktów u prawników rzymskich okresu klasycznego, Toruń 1998.

' J. ZabŁocki, Uwagi o procesie rzymskim w 'Noctes Atticae' Aulusa Geliusa, Warszawa 1999.

${ }^{4}$ W. LiTEWSKI, Rzymski proces karny, Kraków 2003.

${ }^{5}$ P. NiCZYPORUK, Żaloba i ponowne malżeństwo wdowy w prawie rzymskim, Bialystok 2002.

'B. SITEK, Infamia w ustawodawstwie cesarzy rzymskich, Olsztyn 2003.

'T. PALMIRSKI, 'Obligationes quasi ex delicto'. Ze studiów nad źródtami zobowiązań w prawie rzymskim. Kraków 2004.

${ }^{8}$ F. LONGCHAMPS DE BÉRIER, Nadużycie prawa $w$ świetle rzymskiego prawa prywatnego, Wroclaw 2004.
} 
miast przybliżanej we współczesnym ujęciu cywilistycznym, tak w literaturze dotyczącej prawa polskiego ${ }^{9}$, jak i wspólnotowego ${ }^{10}$.

Monografia składa się ze wstępu, zawierającego przedstawienie problemu, metody naukowej i tezy pracy, ośmiu rozdziałów oraz zakończenia, stanowiącego podsumowanie poruszonej tematyki.

Analizując opracowanie Marka Sobczyka można, ze względu na poruszane w nim zagadnienia, dokonać podziału tekstu na trzy części, należy jednak zaznaczyć, iż podział taki nie został wprowadzony przez autora przy redakcji pracy. Wydaje się, iż dokonanie go uczyniłoby układ tekstu bardziej klarownym. W pierwszej tak wyróżnionej części, obejmującej rozdział I, Autor zajmuje się koncepcjami siły wyższej w rzymskich źródłach nieprawniczych, głównie filozoficznych (szczególnie Cycerona i Seneki), wychodząc słusznie z założenia, iż współczesna romanistyka coraz bardziej dostrzega potrzebę uwzględnienia funkcjonowania instytucji prawnych na szerszym tle społecznym" ${ }^{\prime \prime}$ W ramach tych rozważań autor wskazuje kilkanaście terminów, którymi siłę wyższą określają autorzy tekstów nieprawniczych (np. vis maior, vis divina, casus, vis fatalis, vis fortunae, vis calamitosa, vis ventorum i inne), oraz przywołane zostają jej istotne cechy, takie jak przemożność, nieprzewidywalność i nadzwyczajność zdarzeń. Jako główny przykład siły wyższej wskazywane są zdarzenia wywołane przez siły przyrody: powodzie i sztormy morskie ${ }^{12}$, niszczycielska siła ognia ${ }^{13}$, choroby i śmierć nie-

${ }^{4}$ Np. J. S. PiątKowski, Sila wyższa jako podstawa wytaczenia odpowiedzialności $z$ art. 152, 153 k. z., «NP» 19.1 (1963), s. 36 n.; M. OwCZAREK, Sila wyższa jako przestanka zwalniająca $z$ odpowiedzialności deliktowej prowadzącego przedsiębiorstwo wprawiane w ruch za pomoca sit przyrody, «Przegląd Sądowy» 13.1 (2003), s. 51-66.

${ }^{10} \mathrm{~K}$. Magliveras, Force majeure in community law, «European Law Review» 15 (1990), s. 460-471.

"M. SoвCZYK, Sila wyższa w rymskim prawie prywatnym, Toruń 2005, s. 26.

${ }^{12}$ M. SoвCZYK, op. cit., s. 33, 37. Por. G. HAMZA, Einige Anzeichen der rechtsvergleichenden Analyse bei Cicero, «Labeo» 36 (1991), s. 41 i n.

${ }^{13}$ M. SoBczYK, op. cit., s. 33. Na temat pożarów w starożytnym Rzymie i walki z nimi por. P.[K.] GRABowsKI, Strażacy $z$ Wiecznego Miasta, «Przegląd Pożarniczy» 93.12 (2005), s. 28-29 i literatura tam cytowana. 
wolników i zwierząt ${ }^{14}$, atak nieprzyjaciela i działania wojenne. Na podstawie przeanalizowanych źródeł autor formułuje wniosek, iż „poza sferą prawa, w rzymskiej filozofii, literaturze i mowie potocznej istniała szeroka, intuicyjna i z natury rzeczy nietechniczna koncepcja siły wyższej" ’s.

W następnej części pracy, obejmującej rozdziały II-V, Marek Sobczyk przedstawia rozwój koncepcji siły wyższej w rozstrzygnięciach prawników w zależności od epoki. W okresie prawa przedklasycznego i klasycznego wskazuje przede wszystkim na rozwiązanie Serwiusza Sulpicjusza zachowane w D. 19,2,15,2, będące rozstrzygnięciem kwestii rozkładu ryzyka związanego $\mathrm{z}$ dzierżawą gruntu. Pojawia się $w$ tym fragmencie po raz pierwszy w jurysprudencji pojęcie siły wyższej jako takiej siły, której nie można się oprzeć (vis, cui resisti non potest). Następnie autor dokonuje niezwykle rzetelnej i szczegółowej analizy tego pojęcia, odnosząc się również do poglądów innych jurystów: Labeo, Jawolena i Ulpiana.

W rozważaniach poświęconych sile wyższej w rozstrzygnięciach jurysprudencji klasycznej autor dokonuje całościowej syntezy zagadnienia wskazując na poglądy dotyczące możliwych źródeł powstania zdarzenia. Warto zwrócić przede wszystkim uwagę na rozważania dotyczące kwalifikacji aktu władzy i czynu człowieka jako siły wyższej, którym autor poświęcił wiele miejsca w pracy. Wydaje się to słuszną decyzją, ze względu na zbyt skromne poruszanie tego tematu w dotychczasowej literaturze. Na podstawie analizy źródeł autor stawia tezę, iż odwrotnie niż często się to przyjmuje Rzymianie najprawdopodobniej nie zaliczali zdarzeń wynikłych $\mathrm{z}$ aktu władzy i czynu człowieka do kategorii siły wyższej ${ }^{16}$.

Również źródła prawa poklasycznego poruszające temat siły wyższej znalazły gruntowne omówienie w prezentowanej pracy, w szczególności zaś konstytucje cesarzy Karakalli, Aleksandra Sewera i Dioklecjana, jak również cesarzy późniejszych, zebrane

\footnotetext{
${ }^{14}$ M. SовсZYк, op. cit., s. 33.

${ }^{15}$ M. SOBCZYK, op. cit., s. 65.

${ }^{16}$ M. SoвCZYK, op. cit., s. 162.
} 
w Kodeksie Teodozjańskim. W tym miejscu należy jednak wspomnieć, iż jakkolwiek pod względem problemu siły wyższej okres rządów dynastii Sewerów przynosi rozwiązania nowe, odmienne od rozstrzygnięć jurysprudencji klasycznej, to umieszczenie ich konstytucji $\mathrm{w}$ rozdziale dotyczącym prawa poklasycznego koliduje z powszechnie przyjętym w romanistyce podziałem na epoki, zgodnie z którym panowanie Karakalli i Aleksandra Sewera zalicza się do okresu klasycznego. Trzeba jednak przyznać iż autor uzasadnia ten zabieg „niewielką różnicą czasową między nimi, a konstytucjami poklasycznymi" ${ }^{17}$ oraz wskazaniem analogicznego traktowania tych konstytucji w literaturze dotyczącej problemu vis maior ${ }^{18}$. W odniesieniu do tych źródeł autor wskazuje wyraźną zmianę koncepcji siły wyższej, która ewoluowała od precyzyjnej konstrukcji vis, cui resisti non potest $\mathrm{w}$ kierunku dalece mniej precyzyjnych terminów, takich jak fortuna inclemens czy infortunium maioris impetu atque dispendium $^{19}$. Przykład ten znakomicie potwierdza tezę o stopniowym upadku prawa i jurysprudencji rzymskiej w epoce poklasycznej.

Rozdział V opisuje koncepcję siły wyższej w prawie justyniańskim, zwłaszcza w ówczesnym podręczniku Institutiones. Istotną częścią zawartych w nim refleksji autora jest zaprzeczenie popularnej u wielu autorów tezy o wytworzeniu w prawie justyniańskim subiektywnej koncepcji siły wyższej, wskazując liczne zastrzeżenia przeciwko tej teoriii ${ }^{20}$.

Wielokrotnie na kartach pracy pojawia się solidnie udokumentowana teza, iż rzymska koncepcja siły wyższej miała charakter zdecydowanie obiektywny. Warto $\mathrm{w}$ tym miejscu wspomnieć, iż autor wskazuje również na zastąpienie pojęcia custodia pojęciem najwyższej staranności (exactissima diligentia), które dokonało się w tym właśnie okresie. Na uwagę zasługuje wskazanie niezwykle istotnego

${ }^{17}$ M. SOBCZYK, op. cit., s. 163.

${ }^{1 *}$ A. Doll, Von der 'vis maior' zur hoheren Gewalt, Frankfurt am Main-Bern-New York-Paris 1989, s. 116.

${ }^{19}$ M. SOBCZYK, op. cit., s. 294.

2" M. SoвCZYK, op. cit., s. 201-202. 
faktu określania siły wyższej, w starszych źródłach nazywanej vis maior, terminem casus fortuitus, szczególnie w konstytucjach Justyniana, poddanych w książce szczegółowej analizie.

Po omówieniu historycznego rozwoju koncepcji siły wyższej autor przechodzi do omówienia funkcji siły wyższej, dającego się wyodrębnić w trzecią część pracy. Obejmuje ono rozdziały VI-VIII. Przedstawiona jest, z godną uznania precyzją, funkcja siły wyższej jako okoliczności egzonerującej. Omówione zostały takie sytuacje jak np. zwolnienie od odpowiedzialności z tytułu cautio damni infecti, damnum iniuria datum, utrata rzeczy oddanej w zastaw czy też odpowiedzialność z tytułu custodia. Następnie rozważania autora koncentrują się na funkcji siły wyższej jako przesłanki rozkładu ryzyka głównie w kontekście kontraktów sprzedaży i najmu. Ostatni rozdział (poprzedzający zakończenie) przedstawia pozostałe, funkcje siły wyższej, takie jak: uzasadnienie udzielenie restitutio in integrum, wylączenie powstaniu obowiązku prawnego czy też uzasadnienie cessio bonorum.

Jak już wspomniano monografia Marka Sobczyka jest pierwszym polskim opracowaniem podejmującym problematykę siły wyższej w prawie rzymskim. Jakkolwiek nieco zbliżoną tematykę - konstrukcję excusatio necessitatis - przedstawil niegdyś Tomasz Giaro ${ }^{21}$, którego praca wraz z innymi publikacjami wybitnej romanistyki światowej (Max Kaser ${ }^{22}$, Theo Mayer-Maly ${ }^{23}$ i in.) stanowiła ważne odniesienie dla autora, to nie ulega wątpliwości, iz publikacja Sita wyższa $w$ rzymskim prawie prywatnym jako pierwsza monografia poświęcona w całości tematowi vis maior, uzupełnia istotną lukę w literaturze i zwraca uwagę na rzymską konstrukcję tego ważnego w cywilistyce zagadnienia.

Praca jest $z$ pewnością warta uwagi i to nie tylko badaczy prawa rzymskiego. Wydaje się, iż jeszcze więcej wnosi ona do nauki prawa cywilnego, wskazując na starożytny rodowód tak ważnej dla tej

"T. GIARO, 'Excusatio necessitatis' nel diritto romano, Warszawa 1982.

"M. KASER, 'Periculum locatoris', «ZSS» 74 (1957), s. 155-200.

${ }^{23}$ T. MAYER-MALY, s.v. 'Vis maior', «RE» 11. A. 1 (1961), szp. 339-347. 
dziedziny prawa instytucji. Rozwiązania i konstrukcje o których pisze autor znajdują swe zastosowanie do dziś. Szczególnie widocznie zostało to ukazane w tej części pracy, w której autor wskazuje funkcje siły wyższej, szczególnie w kontekście zwolnienia od odpowiedzialności cywilnej, odwołując się zarówno do rozważań wybitnych romanistów ${ }^{24}$, jak i znawców współczesnego prawa cywilnego ${ }^{25}$. $\mathrm{Na}$ uznanie zasługuje również szczegółowe potraktowanie tematu, dogłębna analiza rozlicznych tekstów źródłowych i wyprowadzenie na ich podstawie własnych tez i cennych refleksji, szczególnie na temat klasyfikacji aktu władzy i czynu człowieka jako siły wyższej.

W rozprawie i nie udało się niestety uniknąć drobnych niedociągnięć. Zbyt częste wydają się być powtórzenia omawianej wcześniej tematyki, wynikające z przyjętego przez autora układu, który zakłada osobne omówienie rozwoju historycznego koncepcji siły wyższej w poszczególnych epokach i monograficzne ujęcie każdej z funkcji vis maior. Jak już wcześniej wspominałem, dające się wyodrębnić trzy części pracy (siła wyższa w źródłach nieprawniczych, siła wyższa u jurystów poszczególnych epok, funkcje siły wyższej) nie zostały należycie wyodrębnione w układzie redakcyjnym tekstu. Autor mógł np. wprowadzić podział na części I, II, III i dopiero później na rozdziały. $Z$ drugiej strony jednak przyjęte rozwiązanie, co prawda sprzyjające powtórzeniom, zwiększa walory dydaktyczne pracy oraz ułatwia jej lekturę szczególnie tym odbiorcom, którzy nie zajmują się prawem rzymskim.

Należy też zwrócić uwagę na niekonsekwentne przytaczanie przez Autora rzymskich imion własnych i ich odmiany. Niekiedy odmieniane są imiona lacińskie (np. „Serviusowi ${ }^{26 ”) ~ i n n y m ~ r a z e m ~}$ zaś pojawiają się imiona spolszczone, głównie należące do cesarzy.

\footnotetext{
${ }^{24}$ M. KaSER, op. cit.; G. MaCCORMACK, 'Periculum' «ZSS» 96 (1979), s. 129-172.

${ }^{2}$ Np. R. LongChamps de BÉRIER, Zobowiąania, Poznań 1948, s. 21; T. DYBowSKI, Odpowiedzialność, [w:] Odpowiedzialność prawna przedsiębiorstwa związanego $z$ użyciem sil przyrody. System prawa cywilnego, III. 1: Prawo zobowiazań. Część ogólna, pod red. Z. RADWAŃSKIE(i), Wrocław-Warszawa-Kraków-Gdańsk 1981, s. 166 i n.

${ }^{20}$ M. SOBCZYK, op. cit., s. 73.
} 
Tytułem przykładu - Autor zamiennie stosuje „Cicero” i „Cyceron", nawet na tej samej stronie ${ }^{27}$. Faktem jest, iż w literaturze panuje daleko posunięta dowolność, przeważa jednak opinia, iż starorzymskie osobowe nazwy własne z zasady podlegają spolszczeniu ${ }^{28}$. Wyjątkiem przyjętym na zasadzie usus przez polską romanistykę wydaje się być określenie „Gaius” (nie „Gajusz”).

Monografia Marka Sobczyka Sita wyższa w rzymskim prawie prywatnym dołącza do wspomnianych wcześniej wartościowych opracowań, które pojawily się w romanistyce polskiej w ciągu ostatnich dziesięciu lat. Praca toruńskiego romanisty stanowi cenną prezentację rzymskich odpowiedzi na problemy aktualne również we wspótczesnej cywilistyce i jako taka niewątpliwie zasługuje na uznanie.

Przemysław K. Grabowski*

MareK KurYŁowicz, Prawa antyczne. Wyktad z historii najstarszych praw świata, Wydawnictwo Uniwersytetu Marii Curie-Skłodowskiej, Lublin 2006, ss. 270

Czytelnik poprzednich książek Marka Kuryłowicza, zwłaszcza takich jak Prawo i obyczaje w starozytnym Rzymie czy Prawo rzymskie. Historia - tradycja - wspótczesność, z pewnością bez wahania weźmie do ręki Jego najnowsze opracowanie Prawa antyczne. Wyklad z historii najstarszych praw świata. I nie zawiedzie się. Książka stanowi bowiem bardzo wnikliwy przegląd starożytnych ustawodawstw. W odróżnieniu od dotychczasowych opracowań, jak np. R. Taubenschlaga Prawo rzymskie prywatne na tle praw antycznych, Warszawa 1955 (pomijając już czas jej wydania i opracowanie jedy-

${ }^{27}$ M. SoвCZYк, op. cit., s. 57, odmiennie A. ZıóŁKowskı, Historia Rzymu, Poznań 2005, s. 15.

${ }^{28}$ J. GrZENIA, Stownik nazw wlasnych, Warszawa 2003, s. 29.

* Uniwersytet Warszawski. 